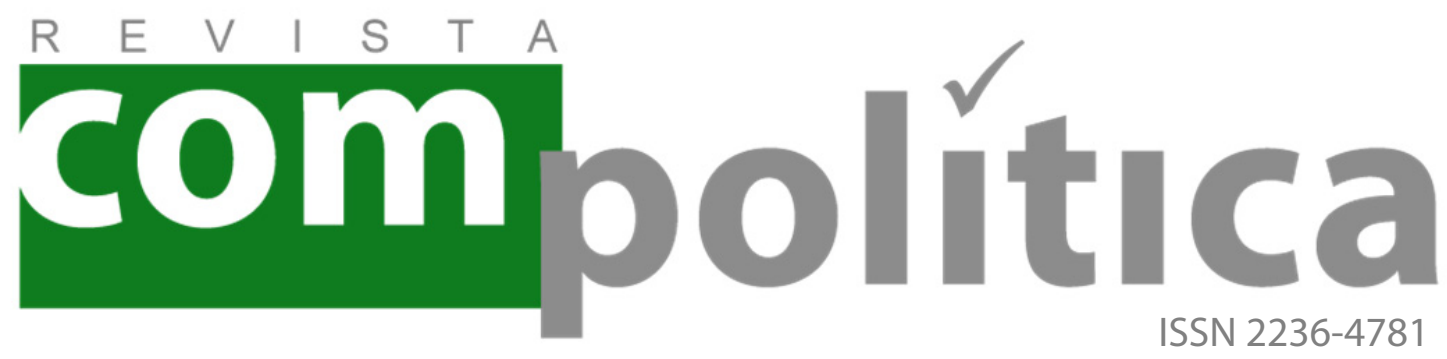

\title{
FERNANDES, Márcio
}

Doutorando-sanduíche da Escola de Comunicação da Universidade Federal do Rio de Janeiro e do Instituto de

Ciências Sociais da Universidade de Lisboa. <marciorf@globo.com>

\section{Um olhar sobre o Turismo Social peronista: aproximações e distanciamentos com regimes autoritários e o New Deal}

RESUMO

Mais do que um regime que tomou de assalto a Argentina nos anos 1940, o Peronismo se configura como sistema de ideias complexo e peculiar, uma identificação (segundo definição de Beatriz SARLO). Este artigo se centra na etapa mais brilhante do Justicialismo (outro nome para o período que tinha em Juan Domingo Perón como seu maior expoente), o Primeiro Peronismo (1946-1955) - e na construção de uma política de difusão do chamado Turismo Social, enquanto um dos braços de um projeto maior levado adiante pela poderosa Subsecretaria de Informaciones. Tal estratégia era fundamentalmente baseada na produção e difusão de posters. Por outro lado, o estudo mostra similitudes e diferencias neste campo para com outros regimes da primeira metade do século 20 (Salazarismo, Franquismo, Fascismo, Nazismo, Stalinismo e New Deal). E mostra como a visão de Michel FOUCAULT de Poder Disciplinar se fazia amplamente presente no Turismo Social peronista.

Palavras-chave: Primeiro Peronismo, Turismo Social, Foucault, Poder Disciplinar.

\section{ABSTRACT}

More than a regime that stormed to Argentina in the 1940s, Peronism is configured as a system of complex ideas and exceptional, a identification (as defined by Beatriz SARLO). This article focuses on the brightest stage og the Justicialism (another name for the period that was Juan Domingo Perón as its greatest exponent), the First Peronism (1946-1955) - and the construction of a policy of spreading the so-called Social Tourism, while one arm of a larger project carried forward by the powerful Central office of Information (SI, in Spanish). This strategy was fundamentally based on the production and dissemination of posters. On the other hand, the study shows similarities and differences in this field to other regimes of the first half of the 20th century (Salazarism, Francoism, Fascism, Nazism, Stalinism and New Deal). And it shows how the vision of Michel FOUCAULT about the Disciplinary Power was largely present in the peronist Social Tourism. Keywords: First Peronism, Social Tourism, Foucault, Disciplinary Power. 


\title{
Um olhar sobre o Turismo Social peronista: aproximações e distanciamentos com regimes autoritários e o New Deal
}

\section{[A look at the Peronist Social Tourism: similarities and differences with authoritarian regimes and the New Deal]}

FERNANDES, Márcio

\begin{abstract}
A té onde é possível perceber, não houve, no mundo ocidental moderno (e mesmo contemporâneo), um projeto similar ao Peronismo argentino e sua proposição, a partir da normalização (seguindo-se aqui o conceito defendido por Michel FOUCAULT) de uma sociedade, de 'construir' uma nação feliz, fazendo-a representar especialmente por meio de cartazes. Em um longo e brilhante ensaio, publicado na segunda metade dos anos 2000, José Pablo FEINMANN sustentou que é algo "diferente, esquivo, no único, pero sin duda específico", suprimindo-o de comparações com o Varguismo, o Fascismo e o PRI mexicano - partido que mandou no país por 60 anos no século 20. Já Flavia FREIDENBERG (2007: 53) enquadrou o regime como um "populismo clásico", enquanto integrantes de uma segunda etapa do Populismo na América Latina - o instante fundador teria se dado nos tempos do presidente argentino Hipólito Yrigoyen.
\end{abstract}

Na América jesuítica dos séculos 17 e 18, a expressão 'terra sem mal' fora cunhada para designar alguns dos aldeamentos em que viviam sacerdotes e indígenas. A crença de que o silvícola americano deixara de ser um sujeito puro - devido ao contato com o europeu - e que era preciso retomar esta condição por meio da conversão ao Cristianismo foi o mote encontrado pelos religiosos para sugerir as vilas jesuítas (também conhecidas como 'reduções') eram lugares felizes. Duradoura, por mais de um século, a proposição da ordem conhecida como Companhia de Jesus abarcou o que hoje são partes dos territórios do Brasil, Uruguai, Argentina e Paraguai.

Este exemplo, e outros que, por ventura, possam ser citados como protótipos de Estados do bem-estar durante os 200 anos seguintes, é um mero arremedo do que o regime protagonizou, sobretudo no 
chamado Primeiro Peronismo (1946-1955), tempo em que experimentou seu auge. Como se verá ao longo deste texto, o rocambolesco era como algo intrínseco ao regime del general Juan Domingo Perón, aí incluindo o chamado Turismo Social, tema ao qual este texto se dedica a partir de certo ponto. Nos séculos 19 e 20, outras experiências em menor escala foram tentadas e, via de regra, fracassaram: dos falanstérios, protótipos de comunidades socialistas, do filósofo francês Charles Fourier em terras da América à Fordlândia paraense (Norte do Brasil), dos Altos Hornos (em San Salvador de Jujuy, Argentina) ao mundo Disney criado por Percival Farquhar na região de Três Barras (Santa Catarina, Brasil), as tentativas de uma sociedade feliz deram em nada em pouco tempo. Mais recentemente, a proliferação de condomínios fechados parece retomar o ideal de um mundo coletivo feliz, ainda que em uma escala menor, quando comparados às projeções de cidades inteiras e países.

Em proporções maiores, a primeira metade do século 20 viu florescer um bom volume de regimes políticos que tentaram seguir o caminho da felicidade, mesmo que, na maioria dos casos, à base de coerção e outros mecanismos pouco sutis. O regime bolchevista na então nova União Soviética foi um deles, com seu ideal de trabalho coletivo e esportes para a juventude. Na Alemanha nazista, os constantes cruzeiros marítimos da Kraft durch Freude (KdF) eram um símbolo deste discurso de mundo paradisíaco que o partido nazi estava disponibilizando a seus conterrâneos - e não é demais contar que Kraft durch Freude pode ser traduzido pelo interessante nome de Força para a Alegria. Na Portugal do ditador António Oliveira Salazar, também havia uma espécie de $\mathrm{KdF}$, a Fnat, diretamente inspirada, por sua vez, na OND italiana, a até hoje famosa ópera Nazionale Dopolavoro. Não fossem esses exemplos suficientes, há de se recordar o case dos Estados Unidos da América, com seus modelos propagandísticos prontos de felicidade dos anos 1930, como parte de uma estratégia para vencer uma profunda crise econômica que pairava sobre o país desde o final dos anos 1920.

O Primeiro Peronismo é de fato o auge de um regime popularesco, nacional popular (uma variante de nacional-socialista), histriônico e outros adjetivos que poderiam facilmente ser listados que permeou o cotidiano argentino de uma maneira ou outra entre os anos 1940 e 1970 - o Segundo Peronismo, já na década de 1970, configurou-se apenas em uma sombra do Primeiro. Referindo-se ao Fascismo, António COSTA PINTO (1994: 149) dizia que o regime de Mussolini, especialmente a partir dos anos 1930, oferecia um modelo aplicável a outros países: era "um regime capaz de eliminar a luta de classes; com apoio das massas e mobilizador; introdutor de um corporativismo sindicalista susceptível de nacionalizar a classe operária; sintetizando valores tradicionalistas de uma latinidade imperial com uma mística de modernidade". Excetuando-se os ímpetos imperialistas e expansionistas, a Argentina peronista teve tudo isso. E mais, o mote de uma sociedade feliz auto-representada, o 
que lhe conferia e confere até hoje um ar de originalidade dentre os tantos 'ismos' que proliferaram até 1950. O foco das atenções peronistas, portanto, era lastreado neste modelo de gestão.

E os niños estavam no epicentro da atenção justicialista (outra denominação para aqueles tempos do regime). Os idosos também, assim como os trabalhadores das zonas urbanas e do mundo rural. A dona de casa faz parte deste rol. Se olharmos bem para as memórias documentadas e as lembranças do Peronismo, será possível se admitir que qualquer argentino de então era prioridade do sistema, já que se pode vislumbrar a enfermeira (e outras tantas ocupações), o morador do campo, o desempregado, etc, o escopo da propaganda peronista. Pode-se parecer paradoxal sustentar que todos os argentinos eram prioridade mas, admite-se também, o Peronismo era ambicioso. Ou falastrão, segundo os oposicionistas.

As pilhas de cartazes produzidas entre 1946 e 1955, propagandeando as virtudes justicialistas, indicam isso, essa ideia de tentáculos para todos os lados. Tais peças gráficas configuram um rico acervo visual de um tempo em que, na letrada Argentina, o desenho, o traço à mão, a habilidade milimétrica do artista era mais importante que o olhar do fotógrafo, por exemplo. Em tais afiches (cartazes), o desenho se sobressai o tempo todo. Nas capas de revistas peronistas, também. Nas bandeiras, nos bottoms, nos cartões postais e assim por diante. Estas peças impressas configuram o cerne da primeira parte da propaganda política do regime, indo de 1946 até meados de 1952, quando o Peronismo 'descobre' de vez as virtudes da imagem em movimento, notadamente o Cinema documental.

O Peronismo, enfim, era um regime de intensa propaganda política visual - fosse ela concebida nas peças gráficas ou realizada em eventos ao ar livre, como um triunfalismo que se assemelha deveras aos principais regimes autoritários e totalitários da primeira metade do século 20. Em 1946, em Paso de los Libres - outro rincão argentino, na fronteira com o Rio Grande do Sul -, quem viu um garboso Juan Domingo Perón (com aquele sorriso a la Carlos Gardel) descer do avião presidencial para inaugurar a ponte internacional que ligaria Libres à brasileira Uruguaiana não esquece esta cena.

Havia mais: a triunfal chegada - Evita também não decepcionou no figurino, ainda que não fosse um corte francês, como ela passaria a usar a partir do ano seguinte - no aeroporto seria pouco diante da inauguração da ponte em si, quando cabos eleitorais peronistas arremessavam pegavam dinheiro de vários sacos e arremessavam para o alto, na direção da plateia, enquanto Peron discursava. A seu lado, um soturno Eurico Gaspar Dutra, o presidente brasileiro daquele período, como bem demonstra a imagem 01, na lista de anexos.

O acervo visual, o vocabulário estético do Peronismo, enfim, é amplo 
e riquíssimo para toda sorte de análise. Não deixa de espantar que, até poucos anos atrás, a questão da propaganda peronista tenha sido relegada nos estudos realizados em especial na Argentina. Gabriel Hernan ROSA (2008: 02) comenta que, por muito tempo, vinha sendo soslayaba (indo pelas margens) por investigadores, sendo considerada mesmos como como grosseira, sem muita influência, portanto, nas relações entre os líderes peronistas (o general e Eva) e as massas. Somente a partir dos anos 1980, continua ROSA, este cenário começou a mudar, mesmo que muito lentamente.

Nesta investigação, o que se busca dimensionar são aspectos, a partir desta cultura imagética de então, do quão profundo foi este 'imperativo da felicidade' da sociedade argentina sob o manto peronista, tendo como mola-mestra a política de controle dos corpos que sonhava com um corpo social homogêneo - uma estratégia que remete claramente ao conceito de 'normalização' prescrito por Michel FOUCAULT. Vide as palavras cristalinas do autor (1981: 153):

As marcas que significavam status, privilégios, filiações, tendem a ser substituídas ou pelo menos acrescidas de um conjunto de graus de normalidade, que são sinais de filiação a um corpo social homogêneo, mas que têm em si mesmos um papel de classificação, de hierarquização e de distribuição de lugares.

Mais do que eventualmente analisar aspectos de um pitoresco governante, há a intenção de se oferecer ao interlocutor deste texto subsídios para que seja possível compreender determinados meandros do Primeiro Peronismo, considerando-o como um regime único na América Latina ao longo do século 20, fosse pela dimensão do país envolvido (a Argentina era, dentre outras qualidades, um colosso agrícola e industrial naquele momento em nível global) ou pelo flerte com práticas comuns em regimes autoritários, totalitaristas e democráticos ao mesmo tempo - cabe dizer que, mesmo indiretamente, a mídia política peronista bebeu em distintas escalas da fonte stalinista - uma ditadura -, do pote salazarista enquanto uma democracia fajuta e do poço democrático do New Deal americano.

Com propriedade, Alberto SPEKTOROWSKI (2002), em um verbete sobre o Peronismo (livro World Fascism: a historical encycplopedia - vol 2, $L-Z$, organizado por BLAMIRES e JACKSON), o definiu com precisão: "Peronism, the most baffling and least understood of all Latin America populist movements, owes its fame to the leader Juan Domingo Perón and his legendary wife, Evita". Muitos anos antes, em 1970, em uma classificação mais caricatural, Hugo NEIRA (1970: 01) havia taxado Perón como um César populista, argumentando que, na América Latina, regimes como o da Argentina haviam sido "mais imaginativos e eficazes do que os seus parentes do ultramar", na medida em que, dentro das dimensões 'partido', 'programa' e 'líder', os latinos (e não apenas a Argentina) haviam considerado esta última 
como a essencial. Disse o autor (idem: 06):

En fin, más simple y más claramente, se puede cemir así el fenómeno; el 'carisma de los dirigentes, los organismos partidarios o bien los Estados populistas han logrado movilizar detrás de ellos las más vastas audiencias políticas del continente. La dimensión popular del fenómeno no es un rasgo más. Es, en nuestra opinión, el rasgo esencial.

Pois é esse Perón que sabia do valor de uma boa e constante propaganda política. Obviamente, não era o único naqueles tempos, nem mesmo na América Latina. Mas era, possivelmente, o mais original, ou melhor (caso original seja um termo forte demais), o mais diferente e capilar entre seus pares. Leopoldo MARECHAL (citado por GENE às páginas 11-12) escreveu no final dos anos 60, mencionando uma conversa que tivera com el general nos primórdios do regime, em que Perón lhe teria dito 'pónganme a mí en la punta de un palo y úsenme como afiche', o que hoje soa como uma frase profética.

Por volta da metade do século 20 , a propaganda política estava em alta, em diversos regimes de governo mundo afora. Maria Luiza CARNEIRO e Boris KOSSOY (2008: 156), em livro organizado por Luís TORGAL e Heloísa PAULO, escreveram que a função da propaganda política

Em qualquer esfera de circulação, alimenta a imagem de um mundo fictício capaz de competir com o mundo real. 0 caos, a desordem, a miséria, a fome, a exclusão e a injustiça social serão, segundo as mensagens sedutoras, superadas pela revolução que promete paz, felicidade, igualdade social, etc.

Os líderes políticos que descobriram isso na mencionada primeira metade do século 20 foram laboriosos na difusão destas mensagens sedutoras. Francisco Campos, um intelectual do Varguismo brasileiro, gostava de discorrer sobre isso. Maurício PARADA (2009: 38), estudando os escritos de Campos, escreveu que

Essa nova teologia política moderna (baseada na presença de um líder como Perón), resultado de uma cultura de massa, não poderia prescindir das novas formas de comunicação e mobilização produzidas para entreter esta mesma massa. Os instrumentos de sugestão, de intensificação, de ampliação, de propagação e de contágio de emoções compõem o centro nervoso da nova política.

PARADA transcreve também falas de Campos em que ele prescreve que, na tal teologia política moderna, não havia país que não estivesse à procura de um homem carismático 'ou marcado pelo destino para dar às aspirações da massa uma expressão simbólica'. Um César, enfim. 


\section{Do Turismo Social}

É no campo do chamado Turismo Social que os sintomas da felicidade crônica começam a ganhar consistência de representações da mídia peronista. A apresentar uma visibilidade maior. O regime criou várias colônias de férias. 'Inventou' Bariloche como centro de lazer no inverno. Expropriou um resort de luxo e transformou-o em um misto de hospital e hotel, Termas de los Reyes, na Cordilheira dos Andes. Mudou nomes de lugares de veraneio. Estatizou terras e colocou lado a lado la burguesia y los obreros. Nunca havia se visto nada igual na Argentina e, é provável, na América do Sul. E assim apresentou seu turismo social:

O mar, a serra, o campo, o Sol e o ar mais puro estão ao
alcance de todos, sem exclusões irritantes, em um
exercício prático de verdadeira democracia, que
pressupõe igualdade de deveres, mas também
igualdade de direitos.

É isto que está descrito à página 171 do livro La Nación... (figura 02). Antes de Perón, diz uma das legendas da página, os endinheirados podiam desfrutar dos bens naturais durante as férias que eles mesmo se concediam quando bem entendiam. Sob o manto justicialista, atesta a legenda seguinte, havia uma lei que estipulava para todos um período de férias remuneradas.

Do ponto de vista do vocabulário estético, há dois itens que devem ser considerados: diferentemente de outros segmentos da propaganda peronista, no campo do Turismo os cartazes chegaram a utilizar fotografias para compor parte do cenário das peças e, em geral, as ilustrações recorriam a personagens caricaturais - e não à representação de uma típica família argentina, por exemplo.

Uma peça de 1955 que divulgava a capital federal, recorda-se, vinha com o mote 'Buenos Aires, puerta de Turismo'. O eixo central do cartaz é um calhambeque colorido, com um casal a bordo. Logo abaixo, está o desenho de uma janela aberta e, dentro desta abertura, um detalhe fotográfico da capital. A obra é assinada por Ernesto Pellisier.

Outras peças criadas por distintos desenhistas recorrem ao mesmo expediente. Era a tática da orquestração, uma das categorias propostas por Abraham MOLES (1970). É o caso de um cartaz que difundia a zona de Embalse, perto de Córdoba (uma das maiores cidades do país vizinho ao Brasil) - imagem 03, do desenhista Valmonti. Outras ilustrações, feitas respectivamente por Valmonti (04) e Glorio (05) seguem o esquema clássico do traço à mão levado adiante pela Subscretaria de Informaciones, a poderosa SI, o braço propagandístico do regime. Mas é na peça 06 que mais aflora o imperativo da felicidade. A obra retrata uma bem vestida família argentina totalmente sorridente. Ao fundo, representações do mar, 
de um hotel termal e das montanhas geladas. Este cenário é arrematado pelo slogan 'turismo para el pueblo'. Considera-se que esta peça é mais impactante que as anteriores (as que contêm caricaturas) pela representação que carrega da típica família feliz que o Peronismo tanto gostava de propalar.

O mote do turismo para el pueblo se faz presente também em La Nación.... Em seis páginas, são apresentadas as possibilidades de veraneio ofertadas pelo sistema. O tema 'turismo' começa na página 455, com um cartaz que remete à paisagem árida do Norte argentino (com os cactos), aos bosques do Sul, às cataratas de Iguazu (na fronteira com o Brasil) e assim por diante. Foz, aliás, era um ponto sendo descoberto aos poucos na época pelos turistas, fomentado pelo Estado (figura 07). A página se encerra com um texto que inicia e finaliza com o que segue:

(Início) A Pátria tem agora suas portas abertas para argentinos e estrangeiros a conheçam. (Final) Um trabalhador ou empregado (qualquer) tem hoje a possibilidade de viajar, de recorrer, de visitar, de conhecer e de viver em qualquer centro de turismo do país. Este é o turismo social.

Mas o que impressiona mesmo no que diz respeito ao turismo social em La Nación... está disposto entre as páginas 456 e 460, em que o Peronismo apresenta um balanço do que, naquele momento (por volta de 1950), estava em funcionamento e o que vinha sendo erigido. 0 monumentalismo se faz deveras presente, conforme o que está descrito nas páginas:

456: quatro parques nacionais criados e outros sete em construção;

457: 33 hotéis familiares mantidos pelo Estado em 1949, capazes de abrigar 2,5 mil hóspedes. A página informa ainda que, seis anos antes, existiam apenas três estabelecimentos do gênero pela Argentina, para 428 hóspedes. Ao cabo do plano de construção de tais casas de veraneio, em 1955, o volume deveria ser de 91 hotéis para 6,5 mil pessoas;

458: outros 21 hotéis em construção em 1949 destinados apenas a trabalhadores ou crianças. Um destes era em Bariloche, outros quatro em Embalse;

459: quando saiu o livro La Nación..., o Peronismo estava construindo um balneário nas cercanias de Buenos Aires em uma área de 31 hectares, que deveria ser capaz de abrigar 50 mil pessoas. Outro espaço, denominado Balneário Escolar, comportaria 30 mil crianças. A piscina, diz a obra, teria inacreditáveis 840 metros de comprimento;

460: o livro também menciona outra área de lazer em funcionamento na época - um balneário às margens do rio Matanza, nas 
proximidades do Aeroporto Internacional de Ezeiza, mandado construir e inaugurado por Perón e que até hoje é o maior daquele país. O texto informa o seguinte:

As piscinas são três: duas delas com $400 \mathrm{~m} \times 100$ metros cada uma e a terceira de $200 \mathrm{~m}$ x $200 \mathrm{~m}$. A profundidade das mesmas varia entre 0,60 e 1,60 m e estão rodeadas de lava-pés. A capacidade total do balneário é de 60 mil pessoas.

Cada piscina, frise-se, podia acomodar 1,5 mil pessoas simultaneamente.

De todos os lugares turísticos peronistas, possivelmente nenhum se assemelhava a Chapadmalal (08). Até então um vilarejo costeiro, antigo, elitizado e distante cerca de $70 \mathrm{~km}$ de Buenos Aires, Chapadmalal recebeu a mão transformadora do regime de pronto a partir da segunda metade dos anos 1940 - chalés, hotéis, confeitarias e outros estabelecimentos do lugar são estatizados ou adquiridos por órgãos de apoio ao sistema, como sindicatos. Dezenoves hospedarias públicas, uma delas exclusivamente infantil, passam a funcionar. Cinemas abrem. Assistência médica gratuita é ofertada. Em 1951, o lugar é subsede dos Jogos Pan-Americanos. Famílias adeptas do Peronismo de todos os cantos do país passam a ter direito de veranear uma vez ao ano na região, como parte do Plan de Turismo Infantil lançado em fevereiro de 1950 e dentro do missal peronista que preconizava 'conhecer o país é um dever', uma campanha possivelmente devota da rooseveltiana See America (figura 09) - na Rússia soviética, campanhas desta natureza igualmente ocorreram, assim como uma variante destinada a visitantes estrangeiros; uma peça de Mikhail Litvak, de 1935, convida a audiência do exterior a conhecer o país viajando pelo expresso transiberiano (figura 10), cuja linha atingia a China.

Em 1954, durante a edição inaugural do Festival de Cinema de Mar de Plata (a $20 \mathrm{~km}$ de Chapadmalal), recorda Carlos RODRIGUEZ (2008), em texto para o jornal Página 12, Perón disse o seguinte o veraneio para-estatal:

Há 10 anos visitei esta cidade e, à época, este era um lugar de privilégio, onde ricos de todo o país vinham a descansar os ócios de toda a vida e de todo o ano. (Agora) Bastaria dizer que $90 \%$ dos que vêm veranear nesta maravilha de cidade são trabalhadores ou empregados espalhados por toda a Pátria.

Os tais 90\%, continua RODRIGUEZ, baseado em informações de PASTORIZA, eram pura retórica, ainda que, informa ele, entre 1953 e 1954, cerca de 24 mil trabalhadores tenham passado pelo Complejo Turístico de Chapadmalal. Nenhum deles pagara nenhum centavo nem pela estadia nem pela viagem ou pela alimentação, assegura o autor. 
Mas Chapadmalal era, enfim, uma das pedras brilhantes do Primeiro Peronismo. Uma vez ao ano, era possível permanecer com a família até três semanas no lugar conforme estabelecia o livreto Reglamento del Turista (foto 11), desde que se apresentasse, entre outros documentos, certidões médicas de boa saúde e de vacinação conta a varíola. Na maioria dos casos (ou seja, outros lugares de descanso), pensava o primeiro-casal, era justo que o turista pagasse a viagem e o Estado, a hospedagem. Era uma política de governo como nunca antes na história argentina, como assegura a mesma Elisa PASTORIZA, autora de um interessante livro publicado em 2011 sob o nome La conquista de las vacaciones - breve história del turismo en la Argentina. Esta mesma opção política, informa a página 275 de La Nación..., fez com que 300 mil alunos viajassem pelo país de ônibus durante o ano de 1948, sempre às expensas governamentais.

Prossegue PASTORIZA (idem: 217):

(Nos locais de veraneio) As crianças iam e vinham neste mundo feliz das férias. (...) Se organizavam jogos, havia espaço para a contação de histórias, além de coros, rondas, teatros, títeres e desenhos animados que procuravam distrair os pequenos. Os passeios ao ar livre, os banhos no mar ou nos arroios eram alternados com aulas de exercícios físicos e de geografia e história que almejavam fixar os primeiros conhecimentos acerca da Pátria.

A domesticação dos corpos pela via turística, enfim, algo que, pouco antes, o Salazarismo havia experimentado. Fernando ROSAS e Brandão de BRITO, em Dicionário do Estado novo - volume II (1996: 376377), relatam a inauguração de uma colônia de férias estatal em 1938 na praia portuguesa de Caparica, com o sugestivo nome 'Um lugar ao Sol', destinada a operários e seus familiares. Dois anos a seguir, seriam abertos dois espaços para veraneio infantil, Foz do Arelho e Praia da Aguda. No caso dos adultos, escrevem os autores (idem), o objetivo era "colocar também sob a tutela do Estado Novo e da sua ideologia o perigoso espaço dos tempos livres e dos lazeres, assegurando o seu preenchimento com actividades lúdicas e culturais consentâneas com a inculcação dos valores ideológicos fundamentais do regime".

O florescimento de uma cultura de turismo (a partir do ato de viajar a lazer) é uma das novidades que a Modernidade do século 20 trouxe. Ema Cláudia PIRES (2003: 04) destaca que a conquista gradual em muitos lugares do regime de férias pagas e a significativa melhoria das vias de transporte e de seus meios (notadamente as rodovias e os automóveis) é um fato preponderante para tal desenvolvimento. "Deste modo", diz a pesquisadora (idem), "a actividade turística democratiza-se gradualmente e, a partir da Segunda Guerra Mundial, massifica-se". Muitos regimes da época souberam apostar neste viés, ainda que a um alto custo para o aparelho estatal - na Argentina, viu-se, o Estado custeava semanas de lazer das famílias, enquanto 
que, em Portugal, o Salazarismo concedia enormes descontos para quem desejava, por exemplo, deslocar-se na malha ferroviária, além de subsídios indiretos para alimentação e hospedagem. Custoso ou não, assistencialista ou não, o Turismo Social floresceu nas mãos peronistas na onda que que, como bem aponta Alain CORBIN (2001: 07), apud PIRES, tornou o tempo disponível para o consumo como um lazer-mercadoria, a partir do pós-II Guerra.

Em As palavras e as coisas: uma arqueologia das Ciências Humanas, FOUCAULT (1981: 07) define as heterotopias como utopias que desabrocham em espaços maravilhosos e lisos, como as vastas avenidas das novas cidades e os jardins bem plantados e cuidados, em uma condição de justaposição. Chapadmalal expropriada era uma destas utopias foucaultianas. Uma alegoria de 2004 (figura 12), pintada por Daniel Santoro, não deixa margem para dúvidas. Tampouco a permite uma historieta presente no livro Alegria (de ensino fundamental), dos anos 1950:

Cuanta gente en la playa! Parecen hormiguitas. Eladio pregunta:

- Papá, como puede venir tanta gente? Nadie trabaja?

El padre le contesta:

- Sí, todos trabajamos. Pero ahora, desde que gobierna el general Perón, todos los obreros y empleados tienen derecho a sus vacaciones. Estos hoteles que ves son para que el obrero gaste menos. Aqui descansa. Luego volverá a su trabajo para producir más.

- Y quién atiende por estos hoteles, papá?

- La Fundación Eva Perón.

Outra utopia guardava relação com o turismo transoceânico dos navios pertencentes ao armador Alberto Dodero, o mesmo personagem que patrocinara boa parte dos custos da viagem de Eva Perón à Europa em 1947, onde estivera gloriosamente por vários países. Dodero chegou a ser um dos mais proeminentes empresários aliados a Perón e detinha concessões de navegação para a Bacia do Rio da Prata e para a Europa, tanto para linhas de passageiros como para transporte de cereais. As grandes embarcações da sua frota levavam, claro, motivos peronistas: o maior orgulho era o SS Presidente Perón (imagem 13), para apenas 74 passageiros, todos em primeira classe, e que fazia o trajeto Buenos Aires-Londres-Buenos Aires. Havia ainda o SS Evita e o 17 de Octubre. Um anúncio da época (figura 14) indica a vida dolce far niente de um punhado de peronistas debaixo dos delicados guarda-sóis.

\section{Dos apontamentos finais}

Observados os casos acima, o interlocutor pode pensar que o Peronismo edificou um 'enorme circo romano para dar equilíbrio a vidas desgastadas', uma expressão cunhada por Christian FERRER, 
em artigo publicado no livro Ser feliz hoje... (FREIRE FILHO, 2010: 171), referindo-se ao consumo de espetáculos e à noção de felicidade obrigatória nos tempos modernos. De fato, o Peronismo era um circo romano mas, ressalta-se, estatísticas corroboram que mudanças profundas se deram por aqueles tempos: PASTORIZA (ibidem: 276) informa que, entre 1945 (um ano antes de Perón assumir a Nação) e 1950 (quando o primeiro mandato estava entrando em seu final), o incremento de turistas em Mar del Plata foi da ordem de quase 100\%, passando de 504 mil pessoas em 1945 para 990 mil cinco anos após. Mar del Plata, uma joia litorânea da elite argentina na década de 1930, havia sido transformada no destino-mor do turismo social engendrado pelo Peronismo.

O Primeiro Peronismo, admite-se hoje, também conteve os traços de uma religião política. Emilio GENTILE (2004: 57-59) listou os quatro elementos de um movimento, partido ou regime que se pretende consolidar como tal:

"Consagra el primado de una entidad colectiva secular, convirtiéndola en el eje de una constelación de creencias y de mitos que definem el significado y el fin último de la existencia social y prescriben los principios de la discriminación entre el bien y el mal" - No modelo peronista, esta entidade coletiva secular era a Nação;

"Formaliza dicha concepción en un código de mandamientos éticos y sociales que vinculan al indivíduo a la entidad sacralizada, imponiendóle la obligación de la fidelidad y de la entrega" - Estes mandamentos sempre foram presentes na vida do regime, desde a simbólica Declaração de Independência Econômica de 1947 até os diversos manuais de doutrinamento. Nos anos 1960-1970, no exílio espanhol, Perón gravava mensagens de atualização doutrinária e publicava textos, como o livreto Actualización política y doctrinaria para la toma del Poder, de 1971. Durante seus três mandatos, também não deixaria de publicar diversos documentos catequistas, muitos dos quais continuam recebendo reedições;

"Considera a sus militantes una comunidad de elegidos e interpreta su acción política como una función mesiánica para el cumplimiento de una misión" - Em Manual del Peronista, um dos itens diz que só outro argentino peronista está no seu nível;

"Instituye una liturgia política para la adoración de la entidad colectiva sacralizada, a través del culto de las instituciones y de las figuras en las que se materializa, y mediante la representación mítica y simbólica de una historia sagrada, periódicamente actualizada en la reiterada evocación ritual de las gestas de la comunidad de los elegidos" - Isto foi bastante notório durante o Primeiro Peronismo. $\mathrm{Na}$ maioria dos casos, o cartaz acabou sendo o suporte principal - e a ilustração, a técnica principal da auto-representação. Exceções situam-se no nível de peças como o documentário produzido pelo 
cineasta americano Edward Cronjager sobre os funerais de Evita em 1952 (cerca de 20 minutos), em que o narrador pondera que a nova religião, fortalecida com a morte física da primeira-dama, continuará a crescer por meio do sorriso das crianças, das lágrimas das mães e da gratidão dos idosos alcançados pelas políticas do regime.

Esta classificação, claro, pode ser aplicada a outros regimes do século 20. Mas é provável que nenhum tenha canalizado tantos esforços para os temas do Mundo Feliz e do Turismo Social. A partir de um aparato de enunciação, como as produções da Secretaria de Informaciones, e de inculcação (como a Fundación Eva Perón, com seus quase intermináveis tentáculos), o Peronismo soube se configurar como algo único.

Em Portugal, utilizando técnicas semelhantes, o Estado Novo salazarista propalou apenas a felicidade enquanto algo possível no meio rural - o regime chegou a determinar a construção de pousadas (figura 15) onde se devia vangloriar a cultura regional em todos os aspectos possíveis. Armando MONTEIRO, em capítulo para o livro Estados autoritários e totalitários e suas representações... (TORGAL e PAULO, 2008: 258-260), abordando aspectos dos livros das classes iniciais difundidos pelo Estado Novo junto às escolas lembrou que, mais do que a pax ruris, eles incitavam a crença de uma felicitas ruris, em consonância com as propagandas do Secretariado de Propaganda Nacional (SPN, mais tarde SNI), equivalente à SI. O próprio Salazar em diversos momentos nos anos 1930, por exemplo, mencionou isso: uma destas oportunidades se deu em um discurso em 28 de maio de 1935, conforme Helena MATOS (2010: 117), dos quais segue um trecho capital:

Mussolini começou, há anos, a campanha a favor dos campos. As cidades são sorvedoras de energias. Há que honrar o campo e dar-lhe os meios bastantes para a cidade não atrair. Se lá tivermos boa água, luz, o telefone, o telégrafo, a telefonia, não precisamos mudar para a cidade. Lá teremos tudo e uma vida mais sã.

Nos Estados Unidos, durante o New Deal rooseveltiano, experimentou-se também um discurso vinculado à ideia da felicidade geral da Nação, como uma tentativa publicitária de se fazer esquecer um pouco a crise econômica que atingira o país no final dos anos 1920. As mídias da época, entretanto, estavam mais ligadas à proposição global de que, produzindo mais e melhor, do ponto de vista econômico, todos seriam mais felizes (figura 16). Vale lembrar a projeção de um mundo americano feliz que se fez presente na Exposição Internacional de NY em 1939, no pavilhão do país. Naquela altura, enquanto Portugal se voltava mais e mais para o discurso da ruralidade (o que era cabal no layout apresentado em $\mathrm{NY}$, em contraposição ao progresso técnico do pavilhão na exposição anterior, em 1937, em Paris), o stand americano pregava progresso e felicidade, uma harmonia possível, segundo o discurso oficial. 
Enquanto isso, na Alemanha, um dos temas mais afeitos ao Nsdap, o partido dominante depois de 1933, era a retratação de um mundo rural feliz. A exemplo do que era fomentado em Portugal, os motes principais guardavam relação com a aversão à Revolução Industrial e o retorno à Natureza. Annette von Droste-Hülshoff, Conrad Ferdinand Meyer, Hermann Löns e Aldabert Stifter são alguns dos principais artistas alemães desta causa na época. E, tal qual na Argentina peronista anos depois - com seus chalecitos e monoblocos gigantescos, formando grandes bairros operários -, as vilas felizes eram parte da estratégia nazi de dominação. Kraft durch Freude gestaltet das schöne Dorf, de Franz Gutsmiedl, é um dos livros a contar a beleza e a ordem seguidas nas casas dos vilarejos, lembra Peter ADAM (1992: 280).

Sobre a KdF anteriormente citada, aliás, é de ressaltar seu caráter biopolítico por completo. Diferentemente da OND italiana, a KdF não era baseada em sindicatos. Seu vínculo era direto com as empresas alemães e, a partir desta ligação, gerenciava a vida de sete milhões de desportistas por volta de 1935. VALENTE (1999: 23) conta que todos os trabalhadores alemães recebiam desconto de $1 \%$ em seus salários, em favor da entidade-mãe da KdF, a Deutsche Arbeits Front (DAF, Frente Alemã para o Trabalho). Em 1938, seria a DAF quem lançaria o primeiro volkswagen (carro para o povo), chamado KdF Wagen.

Talvez o segmento mais visível da $\mathrm{KdF}$ tenha sido sua frota de gigantescos navios de passageiros (figura 17), cujos pacotes prometiam paraísos por alguns dias. Todos os navios tinham classe única. VALENTE (idem) informa que cerca de 700 mil alemães viajaram com a KdF nos anos 1930 , cujos passeios custavam cerca de $50 \%$ abaixo do mercado - há quem defenda que a $\mathrm{KdF}$ tenha sido a maior companhia de navios do planeta na primeira metade do século 20.

Muitos destes cruzeiros faziam escala na Lisboa salazarista. Em uma fala um tanto messiânica, durante uma destas paradas em Portugal, em 1938, Robert Ley, diretor da DAF disse o seguinte (VALENTE, ibidem: 24):

Tudo o que fazemos, este navio, (toda a obra) KdF, tudo serve apenas o objectivo de fortalecer o nosso povo para podermos solucionar esta urgentíssima questão de não termos solo suficiente (...) Não vos conduzimos mundo afora pelo bel prazer, não fundei aqui nenhuma agência de viagens (...) club de animação ou qualquer coisa do género (...) ou apenas para ver a Itália ou Portugal, isso é ridículo e também me é absolutamente indiferente, não, faço-o para que vocês tenham (...) forças, para que o Fuhrer, quando um dia quiser solucionar esta questão, possa contar com 80 milhões (de alemães) no máximo de suas forças.

Era, portanto, o projeto totalitarista a caminho. Para Ley, a propalada 
inexistência de greves ou conflitos econômicos na Alemanha nazi se devia em grande parte à $\mathrm{KdF}$, como uma das grandes entidades orquestradoras do regime Nazi. "Talvez $90 \%$ das pessoas que vêm nesta excursão era inimigas de Hitler antes da sua chegada ao poder. Hoje, como bons alemães que são, estão todos compenetrados do patriótico objectivo do Fuhrer", reiterou Ley, conforme VALENTE (ibid.: 40). À época, uma das palavras preferidas do regime alemão era Gleichschaltung, algo como coordenação ou integrado ao circuito. Toby CLARK (1997: 61) foi direto na sua interpretação da expressão:

Gleichschaltung was the euphemism which Nazis used to describe the enforcement of political conformity. In the press and publishing industries, the education system, and in all art institutions, politically suspect or 'racially impure' people were sacked.

Biopoliticamente falando, CLARK foi preciso. Assim como Robert Ley.

Já na Itália, a administração da felicidade e do turismo social era uma incumbência da Ópera Nazionale Dopolavoro (OND), uma fascinação e uma fixação do regime do Duce (Benito Mussolini), estruturada como uma entidade paragovernamental. Victoria De GRAZIA (2002: 442), em Dizionario del Fascismo - volume I, define o dopolavoro como neologismo criado nos primeiros anos do regime que significava algo como após o trabalho ou tempo livre depois do trabalho, obtido graças à regulamentação da jornada laboral, além de ser o nome da OND, instituída em 1925. Pondera a autora (idem): "O Dopolavoro era constituído por uma multidão de círculos operários, associações e grêmios de recreação em nível local (das cidades) que contava, no final dos anos 1930, com 20 milhões de aderentes".

Em The culture of consent, DE GRAZIA (1981: 24) conta que, enquanto ideia, o dopolavoro é uma invenção americana, tendo sida introduzida na Itália no começo do século 20 pela filial local do grupo ianque Westinghouse. Por sua vez, é de se creditar aos primórdios da Revolução Industrial o advento das primeiras instituições de lazer no formato que as conhecemos e adotamos agora, em decorrência do incremento da sistematização das jornadas laborais.

Dentre as vantagens de estar no sistema da OND, estavam os descontos nos trens populares, as facilidades no comércio, bilhetes mais baratos nos cinemas de sala fixas e nos ambulantes e a chance de participar de concursos musicais. Continua DE GRAZIA (2002: 442): "Graças à OND, foi possível um importante anel de ligação entre o regime e a população, entre a política totalitária e o empenho cívico, entre o centro e a periferia". Havia um OND card, propalado como uma espécie de poupança monetária. "If you lack a card, you lose daily opportunities to save money", sentenciou em 1939 uma das publicações dopolavorianas, recorda a autora (1981: 152). 
Como se nota em todos estes exemplos mundo afora, eram estratégias distintas para fins comuns. Em abrangência, representações e, possivelmente, feitos, nenhum se assemelha ao Peronismo. A Argentina nunca mais se livrou dele, para o bem ou para o mal, algo distinto de outros países. A imagem da família feliz olhando diretamente para seu interlocutor (imagem 06) é demasiada consistente até hoje. A julgar pelos recentes acontecimentos havidos na campanha eleitoral 2011-2012 para a Presidência do país, bem como as estratégias discursivas da companhia aérea estatal Aerolíneas Argentinas (criadas por Perón), não há indícios de os lieux de memoire (expressão usada por Pierre Nora) peronistas estejam a desaparecer ou sequer enfraquecer.

\footnotetext{
Agradecimentos

O autor é bolsista de doutoramento-sanduíche da Coordenação de Aperfeiçoamento de Pessoal de Nível Superior (Capes).
} 


\section{sompolítıca}

n. 2, vol. 2, ed. jul-dez, ano 2012

Anexos - Lista de Imagens

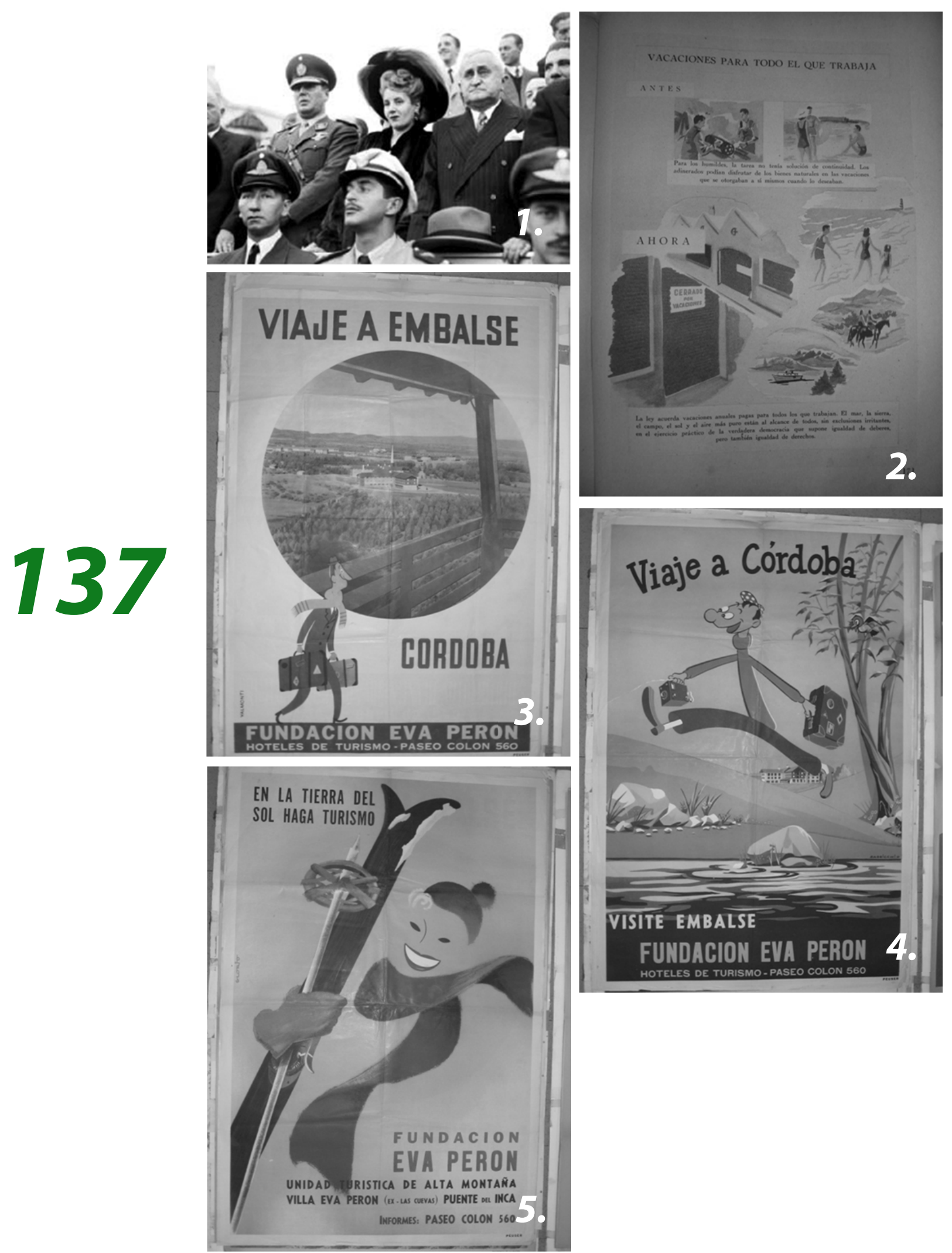



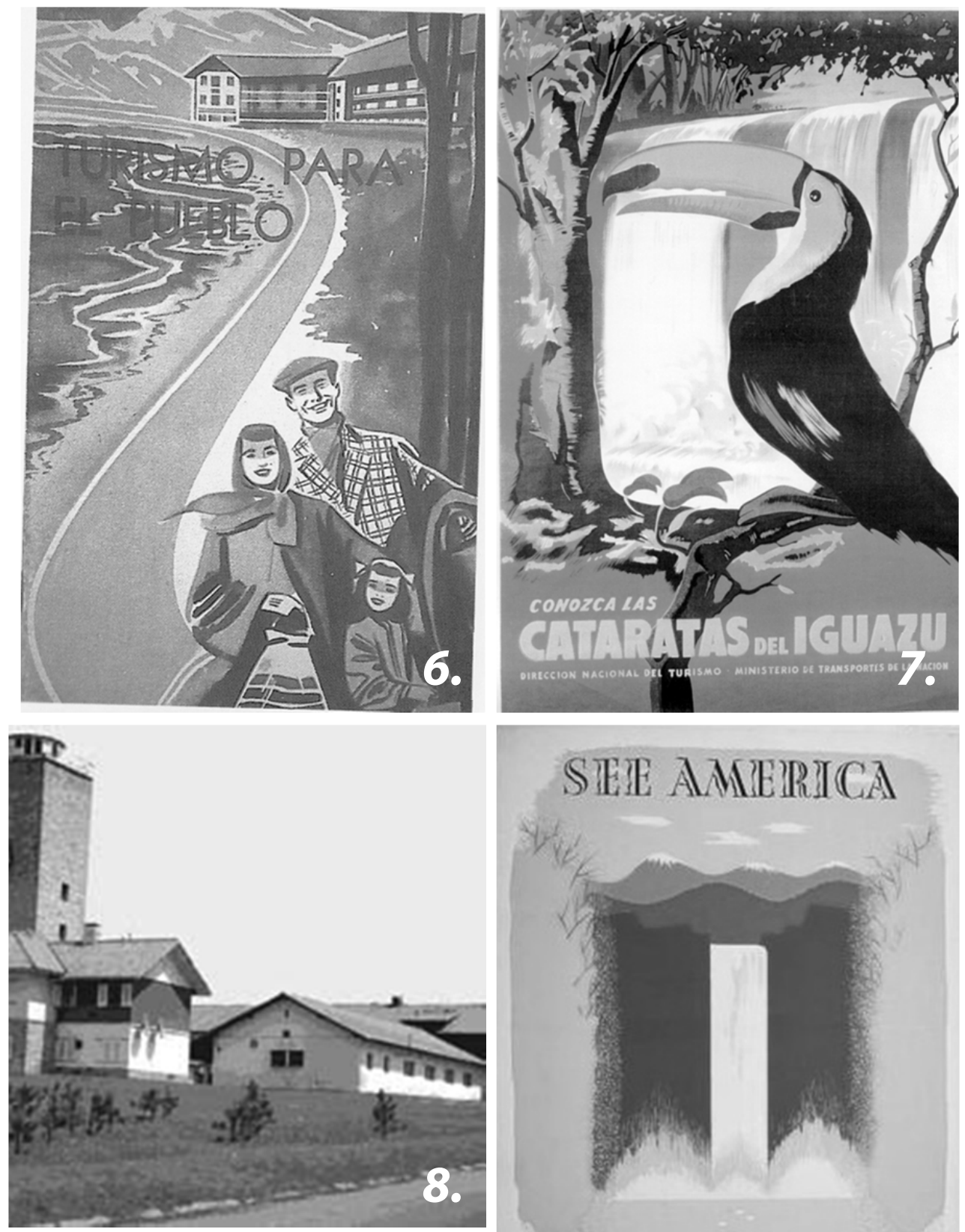

SEE AMEIRICA 


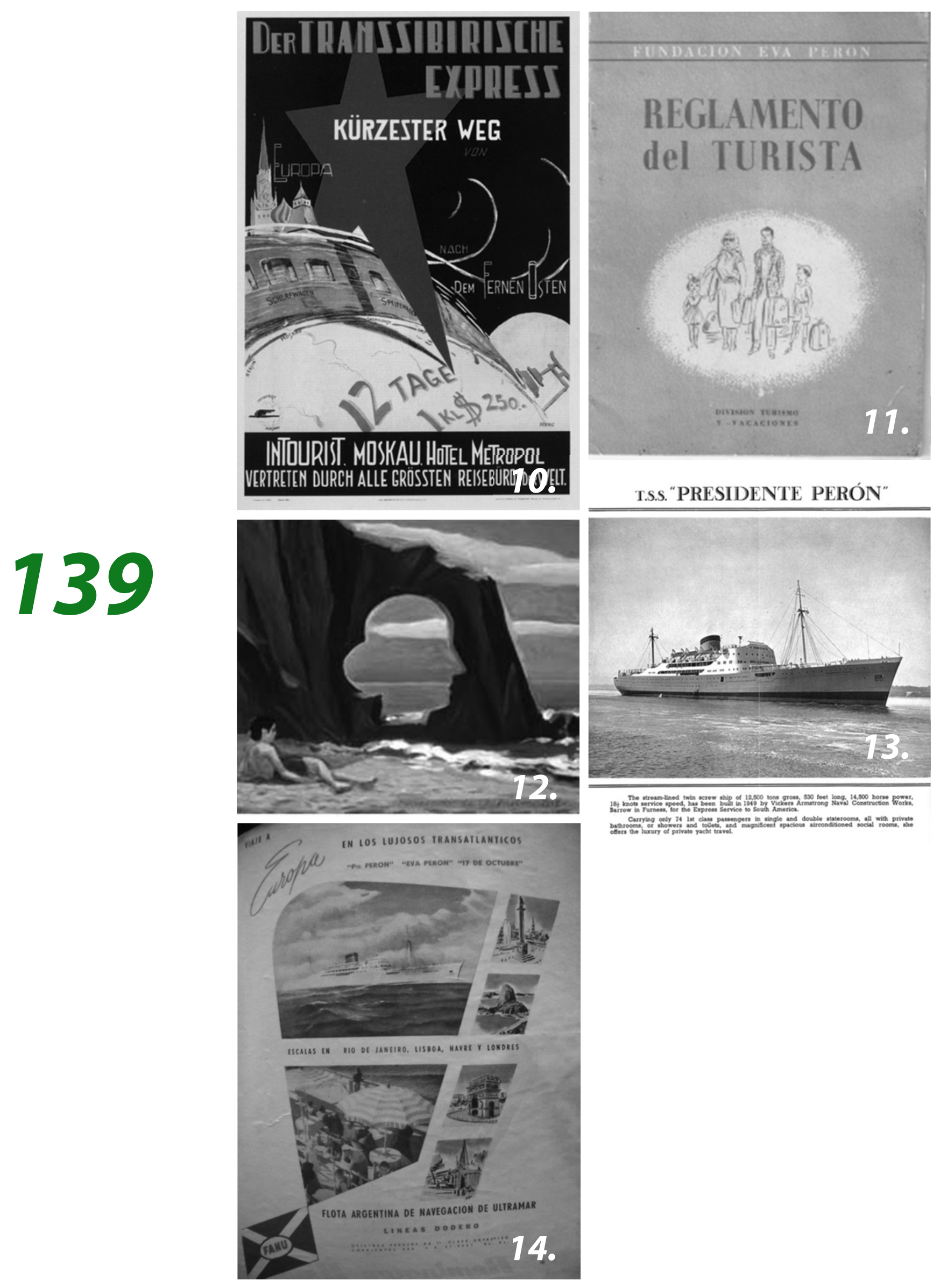



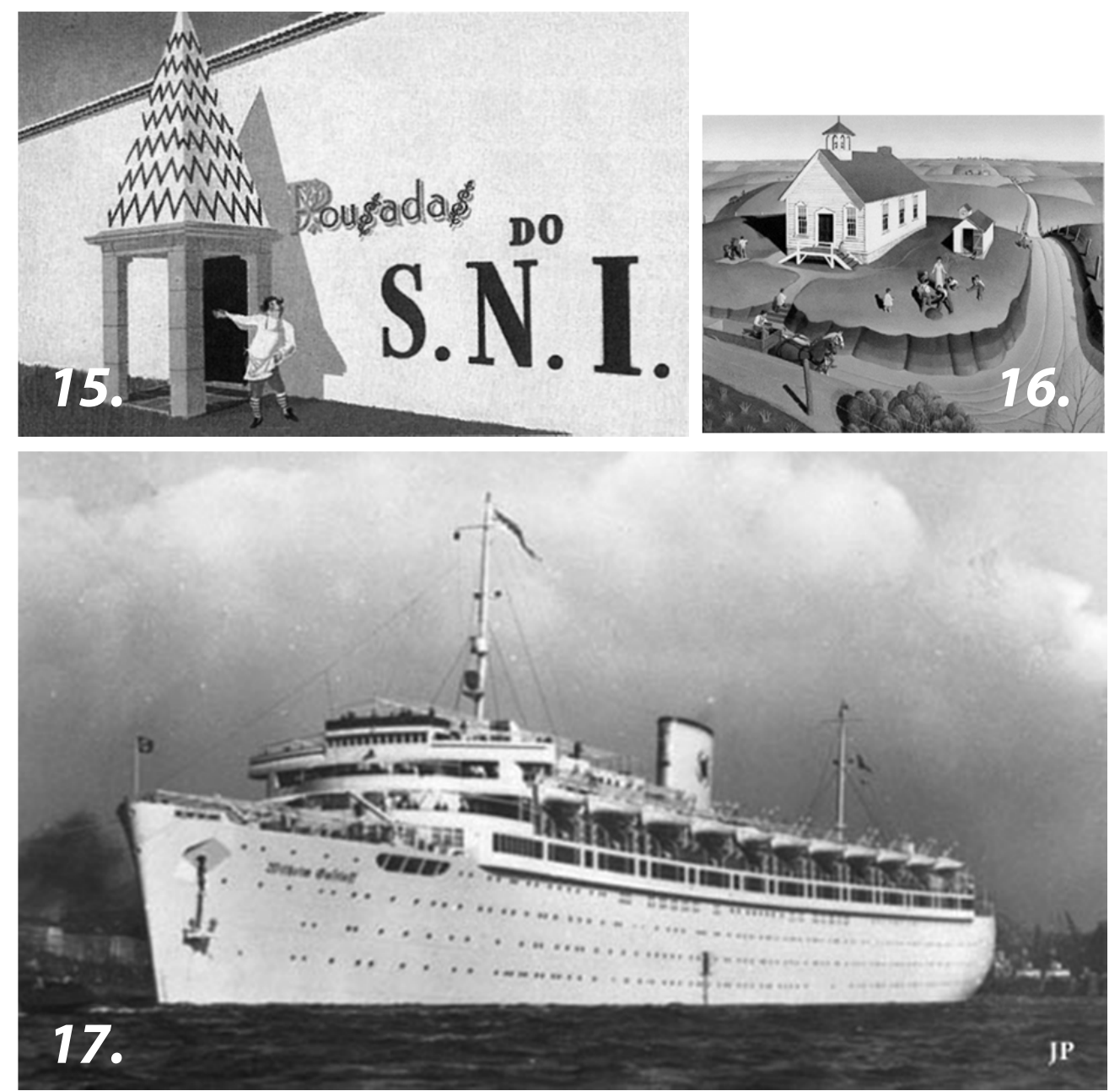


\section{Fontes}

KAPLAN, Wendy (org). Designing Modernity: the arts of reform and persuasion 1885-1945. London: Thames \& Hudson, 1995.

\section{Referências}

ADAM, Peter. The arts of the Third Reich. London: Thames \& Hudson, 1992.

BLAMIRES, Cyprian; JACKSON, Paul (orgs). World Fascism: a historical encycplopedia - vol 2, L - Z. Santa Barbara: ABC Clio, 2002.

CLARK, Toby. Art and Propaganda. London: Calmann \& King, 1997.

DE GRAZIA, Victoria; LUZZATTO, Sergio (orgs). Dizionario del Fascismo - volume I. Torino: Giulio Einaudi, 2002.

The culture of consent: mass organization of leisure in Fascist Italy. Cambrigde: Cambridge University Press, 1981.

FEINMANN, José Pablo. Peronismo, filosofía política de una obstinación argentina. Página 12, Buenos Aires, 2008.

FOUCAULT, Michel. As palavras e as coisas: uma arqueologia das Ciências Humanas. São Paulo: Martins Fontes, 1981.

FREIDENBERG, Flavia. La tentación populista: una vía al poder en América Latina. Madrid: Síntesis, 2007.

FREIRE FILHO, João (org). Ser feliz hoje: reflexões sobre o imperativo da felicidade. Rio de Janeiro: Editora FGV/Globo Universidade, 2010.

GENÉ, Marcela. Un mundo feliz: imágenes de los trabajadores en el primer Peronismo (1946-1955). Buenos Aires: Fondo de Cultura Econmómica, 2008.

MATOS, Helena. Salazar: a propaganda, 1934-1938. Mafra: Círculo de Leitores, 2010.

MOLES, Abraham. L'affiche dans la societé urbaine. Paris: Dunod, 1970.

NEIRA, Hugo. El Cesarismo Populista. Algorta: Zero, 1970

PARADA, Maurício. Educando corpos e criando a Nação - cerimônias cívicas e práticas disciplinares no Estado Novo. Rio de Janeiro: Apicuri/PUC-RJ, 2009.

PASTORIZA, Elisa. La conquista de las vacaciones: breve historia del turismo en la Argentina. Buenos Aires: Edhasa, 2011.

PINTO, António Costa. Os Camisas Azuis: ideologia, elites e movimentos fascistas em Portugal (1914-1945). Lisboa: Estampa, 1994.

PIRES, Ema Cláudia. o baile do Turismo: Turismo e Propaganda no Estado Novo. Casal de Cambra: Caleidoscópio, 2003. 
RODRIGUEZ, Carlos. Mar del Plata, un reflejo de la história del país. Página 12, Buenos Aires, 06 jun. 2008.

ROSA, Gabriel Hernan. Una aproximación al 'modelo de propaganda peronista'. Primer Congreso de Estudios sobre el Peronismo: la primera década, 2008.

ROSAS, Fernando; BRITO, Brandão de (orgs). Dicionário de História do Estado Novo - volume II. Lisboa: Bertrand, 1996.

SARLO, Beatriz. A paixão e a exceção - Borges, Eva Perón, Montoneros. São Paulo/Belo Horizonte: Companhia das Letras, Editora UFMG, 2005.

TORGAL, Luís Reis; PAULO, Heloísa (orgs). Estados autoritários e totalitários e suas representações: propaganda, ideologia, historiografia e memória. Coimbra: Imprensa da Universidade de Coimbra, 2008.

TUSELL, Javier; GENTILE, Emilio; DI FEBO, Giuliana (orgs). Fascismo y Franquismo cara a cara: una perspectiva histórica. Madrid: Biblioteca Nueva, 2004.

VALENTE, José Carlos. Estado Novo e a alegria no trabalho - uma história política da Fnat (1935-1958). Lisboa: Colibri/Inatel, 1999.

A Revista Compolítica é uma revista eletrônica da Associação Brasileira de Pesquisadores em Comunicação e Política. Com periodicidade semestral, sua proposta é difundir a produção acadêmica relacionada às interfaces desses campos de estudo. 